\title{
FACTORS AFFECTING THE PERCEIVED QUALITY OF SERVICE AND PATIENT SATISFACTION ON INPATIENT CARE OF NABIRE HOSPITAL PAPUA
}

\author{
Agustina Utiii ${ }^{1}$, Bhisma Murti ${ }^{1}$, Yulia Lanti Retno Dewi ${ }^{2)}$ \\ Priscilla Jessica Pihahey ${ }^{1)}$ ) \\ 1)Masters Program in Public Health, Universitas Sebelas Maret \\ 2)Faculty of Medicine, Universitas Sebelas Maret \\ ${ }^{3)}$ Health Polytechnics Ministry of Health Sorong, West Papua
}

\begin{abstract}
Background: The government's efforts to improve public health level are by providing excellent health service facilities, including promotion, preventive, curative, and rehabilitative. The outcome of quality health service can be measured by patient perception and satisfaction. This study aimed to examine factors affecting the perceived quality of service and patient satisfaction on inpatient care of Nabire Hospital, Papua, Indonesia.

Subjects and Method: A cross-sectional study was carried out at Nabire regional hospital, Papua, Indonesia, from March to Mey 2020. A sample of 207 inpatients was selected by stratified random sampling. The dependent variable was patient satisfaction. The independent variables were age, income, and length of stay type class health insurance, working, and patient perception toward doctor, nurse, and inpatients facilities. The data were collected by questionnaire and analyzed by a multiple logistic regression.

Results: Inpatients satisfaction decreased with age $\geq 50$ years $(\mathrm{OR}=0.72 ; 95 \% \mathrm{CI}=0.24$ to 2.65 ; $\mathrm{p}=0.720)$, income $\geq$ Papua minimum wage $(\mathrm{OR}=0.77 ; 95 \% \mathrm{CI}=0.22$ to $2.73 ; \mathrm{p}=0.685)$, and length of stay $\geq 7$ days $(\mathrm{OR}=0.13 ; 95 \% \mathrm{CI}=0.03$ to $0.53 ; \mathrm{p}=0.004)$. Inpatients satisfaction increased with class 2 and $3(\mathrm{OR}=1.15 ; 95 \% \mathrm{CI}=0.43$ to $3.07 ; \mathrm{p}=0.773)$, non national health insurance $(\mathrm{OR}=1.21 ; 95 \% \mathrm{CI}=0.46$ to $3.23 ; \mathrm{p}=0.700)$, working $(\mathrm{OR}=2.13 ; 95 \% \mathrm{CI}=0.58$ to 7.85 ; $\mathrm{p}=0.258)$, good patient perception toward doctor $(\mathrm{OR}=3.03 ; 95 \% \mathrm{CI}=1.15$ to $7.99 ; \mathrm{p}<0.001)$, good persepsi patient perception toward nurse $(\mathrm{OR}=4.04 ; 95 \% \mathrm{CI}=1.15$ to $14.17 ; \mathrm{p}<0.001)$, and patient perception toward inpatients facilities $(\mathrm{OR}=26.8 ; 95 \% \mathrm{CI}=11.0$ to $65.32 ; \mathrm{p}<0.001)$.

Conclusion: Inpatients satisfaction decreases with age $\geq 50$ years, income $\geq$ Papua minimum wage, and length of stay $\geq 7$ days. Inpatients satisfaction increases with class 2 and 3 , non national health insurance, working, good patient perception toward doctor, good persepsi patient perception toward nurse, and patient perception toward inpatients facilities.
\end{abstract}

Keywords: inpatients satisfaction, patient perception, health insurance

Correspondence:

Agustina Utii. Masters Program in Public Health. Universitas Sebelas Maret, Jl. Ir. Sutami 36A, Surakarta 57126, Central Java. Email: agustinautii1@gmail.com. Mobile: 081240051451.

The $7^{\text {th }}$ International Conference on Public Health Solo, Indonesia, November 18-19, 2020|361 https://doi.org/10.26911/the7thicph.04.46 